\title{
Competency Based Learning of Interns in Spirometry
}

\author{
Anupinder Thind, Ravdeep Singh, Avnish Kumar, Puneet Gambhir
}

\begin{abstract}
:
Objectives: To establish the knowledge and skill of performing and learning the interpretation of spirometry so that the Indian medical graduate is able to perform and integrate the knowledge of spirometry.

Methods: The study involved undergraduate medical interns posted in the department of medicine in our institution. In this study interns were given competency based training of spirometry. For the learning they were given 1 hour theory as well as practical class demonstrating spirometry. After the class the students performed spirometry and the procedural skills were assessed by directly observed procedural skills (DOPS). After the Performance of the test the interns were given Post-test Questionnaire in which there was significant improvement in their knowledge about spirometry and interpretation of its results.

Result: Highly significant improvement in learning and demonstration of skill of performing and interpretation of the result of spirometry was seen. Hence signifying the need of competency based training in internship.

Conclusion: Learning of spirometry and its interpretation helped the intern to demonstrate adequate skills of performing spirometry and acquire knowledge regarding the utility of spirometer in diagnosing and management of respiratory disorders. These competency based trainings show the effectiveness of hands on training to interns to acquire the desired skills.
\end{abstract}

Keywords: Spirometry, Students, Competency, training, DOPS

\section{Introduction}

During MBBS course the students study about respiratory disorders in physiology, pathology, pediatrics and medicine for the management and diagnosis of respiratory disorders. Spirometry is a common and a beneficial tool for the diagnosis of the respiratory disorders and to observe the course of treatment and management of the disease. Thus knowing the proper utility of spirometer becomes an essential part of learning the management of respiratory disease.[1] This study was designed to enhance the competency of the interns to utilize spirometer to its full potential for the management of respiratory disorders. Competency based training is an outcome based approach that involves identifying the skills acquired by Indian medical graduates (IMG). It involves designing of curriculum to support the achievement and assessment of the communication and technical skills and ability to interpret the results for patient management.[2]

\section{Aims And Objectives}

1. The IMG is competent to perform spirometry

2. The IMG is competent to interpret results of spirometry

3. The IMG is able to integrate knowledge of spirometry to diagnose and manage respiratory disorders

\section{Methods}

1. Study Population: Interns posted in the department of Medicine

2. Duration of study : 6 months

3. Study site : Our institution which is a tertiary care medical institution

4. Sample size: 50 undergraduate medical students doing internship.

5. Data Collection: Students posted in medicine unit will be trained in spirometry by taking 1 hour theory

6. class and 1 hour practical class. Pre and post test will be done. Procedural skills will be assessed by DOPS.

The project was carried out with 50 interns of MBBS that fulfilled the inclusion criteria. They were provided with the information regarding the study, after which consent was taken. Pre-test questionnaire based on the spirometry was filled by them. After filling the questionnaire they were given 1 hour theory as well as practical class on spirometry and its interpretation. The procedural skill of performing spirometry by students was assessed by DOPS Pre training and post training. After the session post -test questionnaire was filled by student and feedback from student was taken.

\section{Planning}

Requisite permissions and approvals were taken from the head of institution, head of department and the institutional ethics committee. 


\section{Discussion with faculty and sensitization}

The first session with the faculty members of Department of Medicine involved sensitization regarding the importance of learning of spirometry, the basic test utilized for lung function tests. Further discussion was carried out as to how the knowledge of interpretation of the results of spirometry would help the student to diagnose and manage various disorders of respiratory system.

Collection of student feedback was done by asking the internship student about learning of spirometry on Likert scale in post test questionnaire.

Evaluation of learning and performing the skill of spirometry was done by faculty doing DOPS

And ability of the intern to utilize the knowledge and interpret the results of spirometry was assessed by Pre and Post test Questionnaire.

\section{Feedback from Student}

Feedback from student was taken on the post -test questionnaire by asking them that have they learned to use and interpret the result of the spirometry. The feedback was taken on Likert Scale, 1- Strongly disagree, 2- disagree, 3- neutral, 4-agree, 5-strongly agree.

\section{Faculty Feedback by Directly Observed Procedural Skills}

There performance was also evaluated by external facilitators as (below average, average, good, very good and excellent).

Table 1. Assessment scores of students using Questionnaire.

\begin{tabular}{|c|c|c|c|c|}
\hline $\begin{array}{c}\text { Questionnaire item } \\
\mathbf{n}=50\end{array}$ & $\begin{array}{l}\text { Pre Test } \\
\text { Mean [SD] } \\
\text { Mean [SD] }\end{array}$ & $\begin{array}{l}\text { t-value } \\
\begin{array}{c}\text { Theory } \\
\text { for spirometry }\end{array}\end{array}$ & $\begin{array}{l}\text { Significance: } \mathrm{p}<0.05, \\
\text { Highly Significant : } \mathrm{p} \\
<0.005\end{array}$ \\
\hline $\begin{array}{c}\text { Indications } \\
\text { for test }\end{array}$ & $9.63 \pm 1.86$ & $8.70 \pm 1.38$ & -6.99 & 0.000000101 \\
\hline $\begin{array}{c}\text { Instructions } \\
\text { for test }\end{array}$ & $6.85 \pm 1.90$ & $8.56 \pm 1.05$ & -5.33 & 0.016896347 \\
\hline $\begin{array}{c}\text { Contraindications } \\
\text { of test }\end{array}$ & $8 \pm 1.39$ & $8.93 \pm 1.11$ & -3.22 & 0.001691248 \\
\hline $\begin{array}{c}\text { Conduction of } \\
\text { spirometry }\end{array}$ & $6.22 \pm 1.12$ & $6.93 \pm 0.68$ & -3.83 & 0.000358401 \\
\hline $\begin{array}{c}\text { Interpretation of results } \\
\text { of spirometry }\end{array}$ & $1.89 \pm 2.10$ & $3.96 \pm 1.29$ & -5.73 & $2.45212 \mathrm{E}-06$ \\
\hline $\begin{array}{c}\text { Total Score of } \\
\text { questionnaire }\end{array}$ & $38.85 \pm 5.72$ & $47.26 \pm 3.94$ & -11.48 & $5.55952 \mathrm{E}-12$ \\
\hline $\begin{array}{c}\text { DOPS } \\
\quad\end{array}$ & $11.08 \pm 3.19$ & $39.23 \pm 7.5$ & -32.17 & $1.94 \mathrm{E}-34$ \\
\hline
\end{tabular}

\section{Results And Discussion}

In the number of 50 interns, 36 strongly agreed and 14 agreed that they learned to use and interpret the result of spirometry. 8 students showed excellent performance, 34 students showed very good performance and 8 students showed good performance.

This study showed that the interns, when provided with the knowledge and training of spirometry which is initially taught in first year MBBS, benefitted more from this learning experience. During internship the intern is more oriented towards implementation of his knowledge while during MBBS final year the student is well versed with respiratory disorders, but may not adequately know how to perform and interpret the result of spirometry.[1] This study showed that IMG benefitted more when the learning was competency based by integration of first year teaching of spirometry in the internship.[3] 


\section{Outcomes:}

In this study the internship student learned to perform and interpret the result of spirometry. IMG gained the competency to perform spirometry and thereafter interpret the result of spirometry and integrate his knowledge to diagnose and manage respiratory disorders.

\section{Limitation:}

1. Loss of student interest in learning

2. Loss of students interest in filling the post test questionnaire

3. The assessment can be biased by previous knowledge attained by interns during group discussions after first batch of students trained.

\section{Conclusion}

Competency based learning is an effective learning practice in Intern students as they have prior knowledge and experience from their MBBS years.[2] Tests like spirometry which require certain expertise to perform and interpret the results can be well taught during internship. This study shows significant results in competency based learning in interns, therefore validates the need for involvement of basic departments too in the training of interns. This study has shown that with requisite competency based training in internship skills can be acquired as per requirements. This aspect can be materialized by proper planning and training of interns to attain the desired competencies under IMG 2014 document till the integrated competency based approach is incorporated in the curriculum of the MBBS course.[4,5]

\section{References}

[1]. Kaminsky DA, Marcy TW, Bachand M, Irvin CG. Knowledge and use of office spirometry for the detection of chronic obstructive pulmonary disease by primary care physicians. Respir Care. 2005 Dec;50(12):1639-48.

[2]. Stodel EJ, Wyand A, Crooks S, Moffett S, Chiu M, Hudson CCC. Designing and Implementing a Competency-Based Training Program for Anesthesiology Residents at the University of Ottawa. Anesthesiol Res Pract. 2015 Dec 21;2015:e713038.

[3]. Wilt TJ, Niewoehner D, Kim C, Kane RL, Linabery A, Tacklind J, et al. Use of spirometry for case finding, diagnosis, and management of chronic obstructive pulmonary disease (COPD). Evid Rep Technol Assess (Summ). 2005 Aug;(121):1-7.

[4]. Weinberger SE, Pereira AG, Iobst WF, Mechaber AJ, Bronze MS, Alliance for Academic Internal Medicine Education Redesign Task Force II. Competency-based education and training in internal medicine. Ann Intern Med. 2010 Dec 7;153(11):751-6.

[5]. Frank JR, Snell LS, Cate OT, Holmboe ES, Carraccio C, Swing SR, et al. Competency-based medical education: theory to practice. Med Teach. 2010;32(8):638-45. 